\title{
Awards and Citations
}

\section{Presentation of the 2018 Paleontological Society Pojeta Award to Eugenie C. Scott}

\author{
Bruce J. MacFadden \\ Florida Museum of Natural History, University of Florida, Gainesville, Florida, 32611, USA <bmacfadd@ flmnh.ufl.edu>
}

The John and Mary Lou Pojeta Award was established by the PS to recognize exceptional professional or public service by individuals or groups in the field of paleontology above and beyond that of existing formal roles and responsibilities. This year, the Pojeta Award Committee includes: Patricia Kelley (UNC-Wilmington), Susan Kidwell (University of Chicago), Caroline Strömberg (University of Washington), and me. This year's recipient is Dr. Eugenie Scott, former Director of the National Center for Science Education.

Genie has been a tireless advocate for important science topics in society, particularly the teaching of evolution. She has been the recipient of many awards, including the National Academy of Sciences Public Welfare Medal in 2010. Genie was an expert consultant in the 2005 landmark decision 'Kitzmiller v. Dover Area School District,' in which the judge ruled in favor of the teaching of evolution, and not intelligent design. Scott has been featured in high-profile print media including The New York Times, Scientific American, The Scientist, and the San Francisco Chronicle, as well as numerous appearances on broadcast media, including MSNBC.
Dr. Scott has authored many scientific publications, including two fundamentally important books-her '2004 Evolution vs. Creationism: An Introduction' and her 2006 book with Glenn Branch 'Not in Our Classrooms: Why Intelligent Design is Wrong for Our Schools.' A physical anthropologist by training, Genie serves as an excellent role model for a scientist who has profoundly impacted society for the better, particularly as related to public understanding of evolution. Genie even has an asteroid named after her!

Her nominators were effusive in praise for her accomplishments, many of which are mentioned above-one noted that: "Genie Scott has been the single most influential advocate of the importance of science education as related to evolution in the United States over the past generation." For these and her other many accomplishments above and beyond normal expectations, we therefore recognized Dr. Eugenie Scott as the recipient of the John and Mary Lou Pojeta Award for 2018 .

November 4, 2018 